\title{
Failure frequency of water supply networks in the Podlaskie voivodeship
}

\author{
Joanna Gwoździej-Mazur ${ }^{1, *}$, and Kamil Świętochowski ${ }^{1}$ \\ ${ }^{1}$ Department of Environmental of Engineering Systems, Bialystok University of Technology, \\ ul. Wiejska 45E, 15-351 Bialystok, Poland
}

\begin{abstract}
This article describes the subject matter of the failure frequency of water supply pipes in Poland. The introduction to the article describes the causes of failures in the water supply network as well as a tool for assessment of the failure frequency of water supply pipes, i.e. damage intensity index. The status of Polish literature concerning the problem of failure frequency of water supply networks is also presented, and attention is paid to the absence of studies within the area of the Podlaskie voivodeship. The research part of the article presents the results of calculations of failure frequency indexes for water supply networks in the Podlaskie voivodeship. Materials from the Central Statistical Office for the period of 2015-2017 served as the basis for studies. Damage intensity indexes throughout the entire Podlaskie voivodeship were analyzed. The status of failure frequency of water supply networks was assessed in poviats of the Podlaskie voivodeship during the years 2015-2017. The mean level of failure frequency of water supply networks was also compared between the Podlaskie voivodeship, other voviodeships and the national average. As a result of calculations that were carried out, reference material was obtained for current and future studies concerning failure frequency of water supply networks in the Podlaskie voivodeship as well as other voivodeships of northern Poland.
\end{abstract}

\section{Introduction}

Failure repair (e.g. water leaks) in water supply pipes is part of a water supply system's operation[1,2]. The occurrence of failures is a direct cause of water leakage from a water supply system[3]. Failures may be responsible for up to $75 \%$ of non-revenue water in a water company. There are many causes of failures [4-8]:

- soil subsidence, tectonic movements and other geological causes,

- material and design defects of pipes, fittings, connectors, etc.,

- excessive loading of the overburden, particularly dynamic loading,

- overloading with many years of exploitation,

- frost penetration to soil in the vicinity of pipe,

- hydraulic shocks,

- high pressure in the network and high daily pressure fluctuations,

\footnotetext{
${ }^{*}$ Corresponding author: j.mazur@.pb.edu.pl
} 
- corrosiveness of soil and groundwater, as well as of water flowing inside pipes,

- stray voltage accompanying electrical traction,

- mining exploitation of mineral deposits.

Despite the fact that pipe failures are a normal phenomenon over the course of exploitation, their number, and thus the amount of water that is irreversibly lost, should be minimized $[9,10]$. The condition of water supply infrastructure as one of many factors affects the safety of water consumers [11-15]. Damage intensity indexes $\lambda$ are determined in the operational practice of a water supply system [16]. According to Kwietniewski [17], the value of damage intensity index $\lambda$ should not exceed:

- for mains $\lambda<0.3$,

- for distribution pipes $\lambda<0.5$,

- for service lines $\lambda<1.0$.

The main area of studies on the failure frequency of water supply pipes in Poland are the southern voivodeships of the country, i.e. the Małopolskie, Śląskie and Podkarpackie voivodeships. The area of southern Poland is characterized by mountainous and piedmont terrain. Meanwhile, Śląsk (Silesia) is an area of intensive mining operations, which translate directly to the failure frequency of water supply networks. Studies by Bergel [18] based on 374 water supply systems in Poland provided important information about the failure frequency of water pipes. Bergel determined the mean level of a Polish water supply system's failure frequency at the level of $\lambda=0.27$ failures $/ \mathrm{km} /$ year [18]. This study is an important point of reference for assessment of other water supply systems. Works [6, 19-24] provide further and increasingly more recent results with regard to the failure frequency of water supply pipes in southern Poland. Poland is lacking studies on the areas of central and northern Poland. Central and northern Poland are characterized by lowland areas. The problem of failure frequency of water supply pipes in this area is touched upon in the works of Gwoździej-Mazur and Świętochowski [7, 25]. Comparing the water supply systems of central Poland with values for areas where mining damage occurs may result in an excessive tolerance for failures occurring in water supply systems in the northern part of the country. Therefore it is justified to conduct studies intended to provide information about the current level of failure frequency of water supply networks in the northern regions of the country.

\section{Material and methods}

The Podlaskie voivodeship is administratively divided into 17 poviats (including 3 cities under poviat rights). 118 municipalities, including 13 urban municipalities, 27 urban-rural municipalities and 78 rural municipalities, are distinguished within the entire voivodeship.

At the end of 2017 , over $13,544 \mathrm{~km}$ of water supply distribution network was functioning within the Podlaskie voivodeship. Water supply networks supplied water to consumers through 197,128 service lines, which translates to a mean density of 14.6 service lines $/ \mathrm{km}$ of distribution network.

Analyses of failures in water supply networks in the Podlaskie voivodeship were carried out based on data (the length of the distribution network pipes, the number of failures) from the Central Statistical Office for the years 2015-2017 [26]. The presented results describe the failure of whole systems without division into main, distribution and connection pipes. The damage intensity index and data from the literature were used to assess and determine failure frequency and its level. 

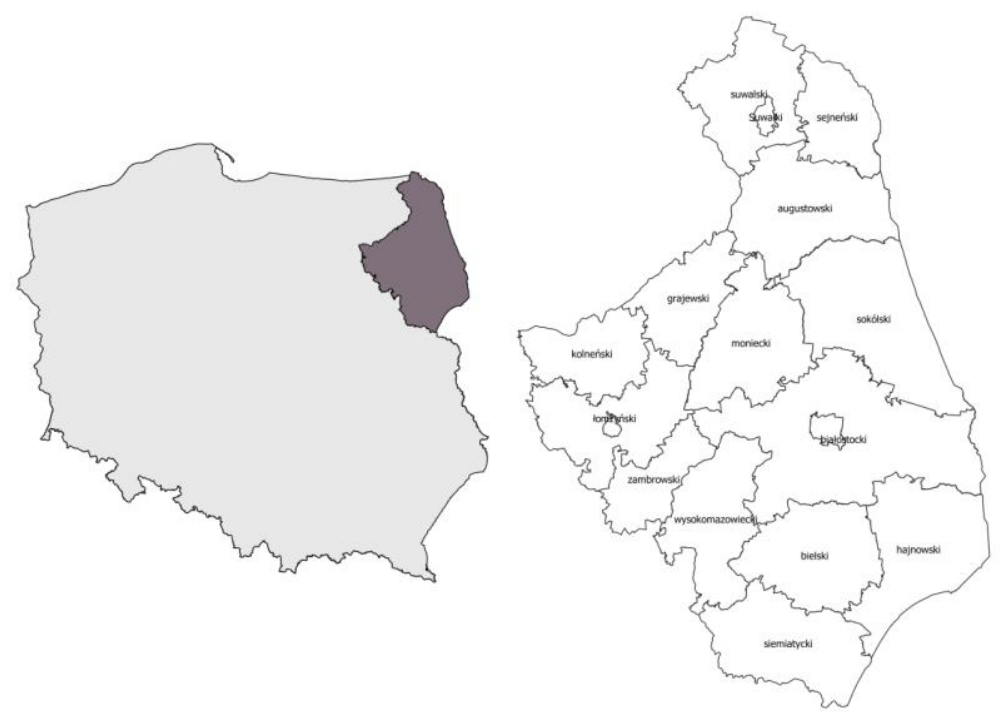

Fig. 1. Location of the Podlaskie voivodeship and division of the voivodeship into poviats.

Failure frequency index [27]:

where:

$$
\lambda(\Delta \mathrm{t})=\mathrm{n}(\Delta \mathrm{t}) / \mathrm{L} \cdot \Delta \mathrm{t}(1)
$$

$\lambda(\Delta t)$ - unit failure intensity, fail/(km·a)],

$n(\Delta t)$ - number of failures within time interval $\Delta \mathrm{t}$,

$L$ - length of pipes tested within time interval $\Delta \mathrm{t}$ (mean length within this interval), $\mathrm{km}$,

$\Delta t$ - considered time interval, year.

The ranges described by Kwietniewski served as the basis for assessment of obtained values of the damage intensity index [7]:

- low failure frequency, when $\lambda \leq 0.1$,

- medium failure frequency, when $0.1<\lambda \leq 0.5$,

- high failure frequency, when $\lambda>0.5$.

\section{Results}

Failure frequency of water supply networks in Poland decreased from the value of 0.30 in 2015 to 0.27 in 2017. The lowest mean failure frequency indexes $(\lambda$, fail/( $\mathrm{km} \cdot \mathrm{a})$ ) for voivodeships were obtained in the Lubelskie voivodeship in the years 2015-2016 and in the Lubelskie and Wielkopolskie voivodeships in 2017. The highest failure frequency was noted in the Śląskie voivodeship. In the Podlaskie voivodeships, the mean failure frequency of water supply pipes decreased from the value of 0.26 in 2015 to 0.23 in 2017 . Failure frequency of water supply pipes during the period of observation was lower than the mean value for the entire country.

In 2015 , the highest failure frequency indexes $\left(\lambda_{2015}\right.$, fail/( $\left.\left.\mathrm{km} \cdot \mathrm{a}\right)\right)$ of water supply pipes were noted in the Śląskie, Dolnośląskie, and Małopolskie voivodeships, and the lowest in the Lubelskie, Wielkopolskie and Mazowieckie voivodeships. In 2016, the highest failure frequency indexes $\left(\lambda_{2016}\right.$, fail/(km·a)) of water supply pipes were noted in the Śląskie, Dolnośląskie, and Małopolskie voivodeships, and the lowest in the Lubelskie, KujawskoPomorskie, Lubuskie, Lódzkie and Mazowieckie voivodeships. In 2017, the highest failure frequency indexes $\left(\lambda_{2017}, \mathrm{fail} /(\mathrm{km} \cdot \mathrm{a})\right)$ of water supply pipes were noted in the Śląskie, 
Małopolskie and Dolnośląskie voivodeships, and the lowest in the Lubelskie, Wielkopolskie and Łódzkie voivodeships.

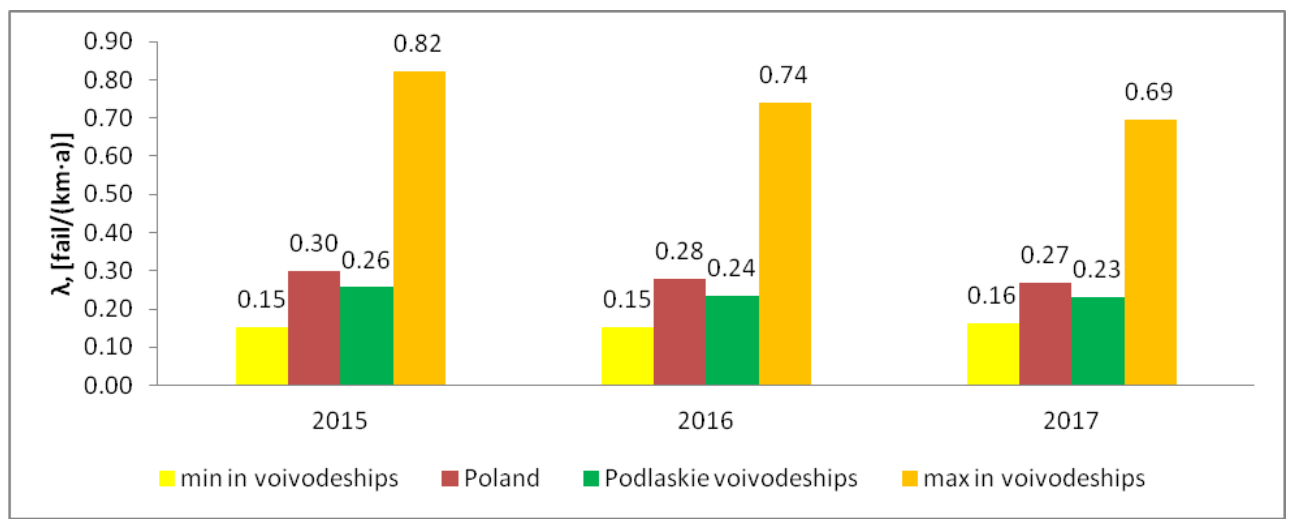

Fig. 2. Mean failure index of a water supply network in the years 2015-2017.

Table 1. Mean failure indexes of a water supply network in voivodeships.

\begin{tabular}{|c|c|c|c|}
\hline \multirow{2}{*}{ Voivodeship } & $\lambda, \mathbf{f a i l} /(\mathbf{k m} \cdot \mathbf{a})$ & $\lambda, \mathbf{f a i l} /(\mathbf{k m} \cdot \mathbf{a})$ & $\lambda, \mathbf{f a i l} /(\mathbf{k m} \cdot \mathbf{a})$ \\
\cline { 2 - 4 } & $\mathbf{2 0 1 5}$ & $\mathbf{2 0 1 6}$ & $\mathbf{2 0 1 7}$ \\
\hline Dolnośląskie & 0.46 & 0.38 & 0.36 \\
\hline Kujawsko-pomorskie & 0.22 & 0.20 & 0.19 \\
\hline Lubelskie & 0.15 & 0.15 & 0.16 \\
\hline Lubuskie & 0.22 & 0.20 & 0.22 \\
\hline Lódzkie & 0.20 & 0.20 & 0.19 \\
\hline Małopolskie & 0.43 & 0.40 & 0.42 \\
\hline Mazowieckie & 0.19 & 0.20 & 0.17 \\
\hline Opolskie & 0.37 & 0.25 & 0.30 \\
\hline Podkarpackie & 0.27 & 0.23 & 0.23 \\
\hline Podlaskie & $\mathbf{0 . 2 6}$ & $\mathbf{0 . 2 4}$ & $\mathbf{0 . 2 3}$ \\
\hline Poland & $\mathbf{0 . 3 0}$ & $\mathbf{0 . 2 8}$ & $\mathbf{0 . 2 7}$ \\
\hline Pomorskie & 0.35 & 0.31 & 0.29 \\
\hline Śląskie & 0.82 & 0.74 & 0.69 \\
\hline Świętokrzyskie & 0.26 & 0.28 & 0.28 \\
\hline Warmińsko-mazurskie & 0.28 & 0.28 & 0.27 \\
\hline Wielkopolskie & 0.18 & 0.18 & 0.16 \\
\hline Zachodniopomorskie & 0.35 & 0.35 & 0.34 \\
\hline \multicolumn{2}{|c|}{} \\
\hline
\end{tabular}

Failure frequency indexes were calculated for every municipality of the Podlaskie voivodeship in the years 2015-2017. In 2015, the lowest minimum index, $\lambda=0$ fail. $/ \mathrm{km} /$ year, was reached in the Hajnowski, Kolneński and Siemiatycki poviats. In 2016, the lowest index, $\lambda=0$ fail./km/year, was reached in the Białostocki, Grajewski, Siemiatycki and Sokólski poviats. In 2017, the lowest index, $\lambda=0$ fail./km/year, was reached in the Białostocki, Grajewski, Hajnowski, Kolneński, Łomżyński and Sokólski poviats. The results of $\lambda=0$ fail. $/ \mathrm{km} /$ year occurred in various communes in poviats in different years. Impact on such a result $\lambda=0$ fail. $/ \mathrm{km} /$ year could be incomplete data in companies associated with poor care for the failure logs or lack of them. The highest minimum index in the years 2015-2017 was noted in the poviat of the city of Białystok (2015 - 0.34 fail./km/year, $2016-0.31$ fail./km/year, $2017-0.37$ fail. $/ \mathrm{km} /$ year $)$. Based on the lowest values of the damage intensity index for municipalities, it can be stated that, 
during the studied period, 5 poviats had low failure frequency of water supply pipes, and 12 poviats were characterized by medium failure frequency of water supply pipes.

Table 2. Failure frequency indexes of the water supply network in poviats of the Podlaskie voivodeship.

\begin{tabular}{|c|c|c|c|c|c|c|c|c|c|}
\hline \multirow[b]{2}{*}{ Poviat } & \multicolumn{3}{|c|}{$\lambda_{2015}$, fail $/(\mathrm{km} \cdot \mathrm{a})$} & \multicolumn{3}{|c|}{$\lambda_{2016}$, fail $/(\mathrm{km} \cdot \mathbf{a})$} & \multicolumn{3}{|c|}{$\lambda_{2017}$, fail $/(\mathrm{km} \cdot \mathbf{a})$} \\
\hline & $\begin{array}{c}\text { mean in } \\
\text { poviat }\end{array}$ & $\begin{array}{l}\text { min in } \\
\text { poviat }\end{array}$ & $\begin{array}{l}\max \text { in } \\
\text { poviat }\end{array}$ & $\begin{array}{c}\text { mean in } \\
\text { poviat }\end{array}$ & $\begin{array}{l}\text { min in } \\
\text { poviat }\end{array}$ & $\begin{array}{l}\max \text { in } \\
\text { poviat }\end{array}$ & $\begin{array}{c}\text { mean in } \\
\text { poviat }\end{array}$ & $\begin{array}{l}\text { min in } \\
\text { poviat }\end{array}$ & $\begin{array}{l}\text { max in } \\
\text { poviat }\end{array}$ \\
\hline Augustowski & 0.27 & 0.03 & 1.70 & 0.24 & 0.03 & 1.43 & 0.20 & 0.02 & 0.97 \\
\hline Białostocki & 0.39 & 0.02 & 3.57 & 0.32 & 0.00 & 3.15 & 0.26 & 0.00 & 3.22 \\
\hline Bielski & 0.59 & 0.09 & 1.52 & 0.52 & 0.11 & 1.32 & 0.54 & 0.09 & 1.37 \\
\hline Grajewski & 0.13 & 0.01 & 0.38 & 0.13 & 0.00 & 0.40 & 0.11 & 0.00 & 0.34 \\
\hline Hajnowski & 0.28 & 0.00 & 1.75 & 0.20 & 0.00 & 0.87 & 0.19 & 0.00 & 0.83 \\
\hline Kolneński & 0.16 & 0.00 & 0.94 & 0.15 & 0.05 & 1.00 & 0.15 & 0.00 & 0.73 \\
\hline Łomżyński & 0.18 & 0.02 & 1.35 & 0.18 & 0.02 & 0.85 & 0.23 & 0.00 & 1.27 \\
\hline $\begin{array}{l}\text { Poviat of the } \\
\text { city of } \\
\text { Białystok }\end{array}$ & 0.33 & 0.33 & 0.33 & 0.31 & 0.31 & 0.31 & 0.37 & 0.37 & 0.37 \\
\hline $\begin{array}{l}\text { Poviat of the } \\
\text { city of } Ł \text { omża }\end{array}$ & 0.18 & 0.18 & 0.18 & 0.26 & 0.26 & 0.26 & 0.24 & 0.24 & 0.24 \\
\hline $\begin{array}{l}\text { Poviat of the } \\
\text { city of Suwałki }\end{array}$ & 0.34 & 0.34 & 0.34 & 0.24 & 0.24 & 0.24 & 0.25 & 0.25 & 0.25 \\
\hline Moniecki & 0.15 & 0.02 & 0.46 & 0.13 & 0.03 & 0.57 & 0.09 & 0.02 & 0.28 \\
\hline Sejneński & 0.22 & 0.04 & 0.86 & 0.22 & 0.04 & 0.71 & 0.24 & 0.03 & 0.86 \\
\hline Siemiatycki & 0.29 & 0.00 & 1.35 & 0.20 & 0.00 & 1.12 & 0.22 & 0.04 & 0.84 \\
\hline Sokólski & 0.17 & 0.02 & 0.93 & 0.16 & 0.00 & 1.04 & 0.15 & 0.00 & 0.98 \\
\hline Suwalski & 0.12 & 0.01 & 0.34 & 0.15 & 0.05 & 0.37 & 0.21 & 0.03 & 0.51 \\
\hline $\begin{array}{c}\text { Wysokomazowi } \\
\text { ecki }\end{array}$ & 0.31 & 0.02 & 2.44 & 0.34 & 0.02 & 2.59 & 0.34 & 0.02 & 3.28 \\
\hline Zambrowski & 0.22 & 0.15 & 0.48 & 0.25 & 0.02 & 0.78 & 0.16 & 0.08 & 0.44 \\
\hline
\end{tabular}

In 2015 , the lowest mean index, $\lambda=0.12$ fail. $/ \mathrm{km} /$ year, was reached in the Moniecki poviat. In 2016, the lowest index, $\lambda=0.13$ fail. $/ \mathrm{km} /$ year, was reached in the Grajewski and Moniecki poviats. In 2017, the lowest index, $\lambda=0.11$ fail. $/ \mathrm{km} /$ year, was reached in the Grajewski poviat. The highest mean index in the years $2015-2017$ was noted in the Bielski poviat (2015 - 0.59 fail./km/year, $2016-0.52$ fail./km/year, $2017-0.54$ fail./km/year). Based on the mean values of the damage intensity index for municipalities, it can be stated that, during the studied period, 1 poviat had high failure frequency of water supply pipes, and the other poviats were characterized by medium failure frequency of water supply pipes.

In 2015 , the lowest maximum index, $\lambda=0.18$ fail. $/ \mathrm{km} /$ year, was reached in the poviat of the city of Łomża. In 2016, the lowest maximum index, $\lambda=0$ fail. $/ \mathrm{km} / \mathrm{year}$, was reached in the Białostocki, Grajewski, Siemiatycki and Sokólski poviats. In 2017, the lowest maximum index, $\lambda=0.24$ fail. $/ \mathrm{km} /$ year, was reached in the poviat of the city of Suwałki. The highest maximum index in the years 2015-2017 was noted in the Białostocki poviat (2015 - 3.57 fail./km/year, 2016 - 3.15 fail./km/year, 2017 - 3.22 fail./km/year). Based on the lowest values of the damage intensity index for municipalities, it can be stated that, during the studied period, 13 poviats had high failure frequency of water supply pipes, and 4 poviats were characterized by medium failure frequency of water supply pipes. 


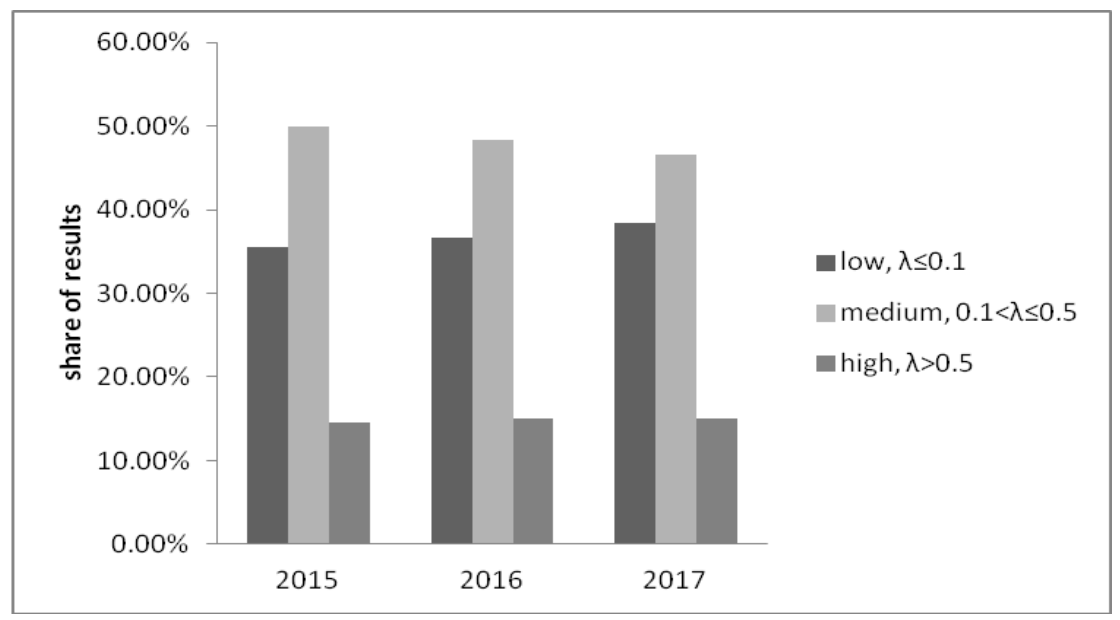

Fig. 3. Failure assessment of water supply in Podlasie voivodship in the years 2015-2017.

The largest number of water supply (individual municipalities) in the Podlasie voivodeship in 2015-2017 was characterized by average failure rates. Low failure rate ranged from $35.5 \%$ to $38.4 \%$ of water supply. The high failure rate was characterized by between $14.5 \%$ and $15.1 \%$ of water supply. In 2015-2017, the number of high and low failure water supply increased. The number of medium failure rate water supply is decreasing.

\section{Summary}

During the period of study, 2015-2017, the Podlaskie voivodeship was characterized by a general failure frequency index of waters supply pipes below the national average. During the period of study, the failure frequency index of water supply pipes in the Podlaskie voivodeship was not one of the three lowest values in the country. Considering the mean values of damage intensity indexes of water supply pipes in poviats of the Podlaskie voivodeship, it can be assessed that the Podlaskie voivodeship is characterized by medium failure frequency of water supply pipes (over $94 \%$ are characterized by medium failure frequency). Conducted studies and analyses constitute a good foundation and point of reference for the characterization of individual water supply systems in the Podlaskie voivodeship during the years 2015-2017, and also serve as a point of reference for assessment of the failure frequency of water supply systems in the Podlaskie voivodeship in future years.

Basic data on water supply collected from the Central Statistical Office do not contain information on breakdowns, on the number of failures in individual months and on the age or material on which the failure occurred. Considering the purpose for which research and analysis were carried out, they are sufficient. According to the authors, the results presented in the article are a good reference point for comparing the results used in studies and analyzes of individual water systems (in which you can focus, for example, on the age of pipes, material, type of pipes). Completed calculations and presented results supplement the basic gap in the Polish literature on the subject of waterline failure regarding information on the failure frequency of the lowland water supply in Poland. Comparing the failure rate in water supply in the Podlasie voivodship to the water supply of the mountain areas or mining damage areas is incorrect and would show the Podlaskie water supply as an almost 
perfect condition. This article is a good starting point for further, detailed research on the failure of water supply in the Podlasie voivodship.

This study supplements the studies of Polish researchers of the subject matter of failure frequency of water supply systems in Poland, which until now have mainly been focused on the area of southern Poland.

\section{References}

1. S. J. F. Gould, Water Scien. Techn. 63 (2011)

2. A. Pagano, Water Res. Manag. 32 (2018)

3. J. B. Martínez-Rodríguez, I. Montalvo, J. Izquierdo, Water Resour. Manag. 25 (2011)

4. H. Hotloś, Env. Protection, 1 (2003)

5. S. Jeewon, Procedia Engin. 119, (2015)

6. A. Kuliczkowski, A. Parka, G. Stefański, Instal, 2 (2013)

7. J. Gwoździej-Mazur, K. Świetochowski, B. Kaźmierczak, Econ. and Environ. 2, (2018)

8. L. Berardi, R. Ugarelli, J. Rostum, O. Giustolisi, Water Resour. Res. (2014)

9. Y. Kleiner, B. J. Adams, J. S. Rogers, Journal of Comp. Civil Engin. 15 (2001)

10. R. Sadiq, Y. Kleiner, B. Rajani, Jour. of Wat. Sup. Res. and Techn.-AQUA, 53 (2004)

11. W. Balcerzak, S. M. Rybicki, Jour. of Wat. Sup. Res. and Techn.-AQUA, 60 (2011)

12. R. Jafar, I. Shahrour, I. Juran, Math. and Comp. Mod. 51 (2010)

13. D. Szpak, B. Cecilia, E3S Web of Conf. 44 (2018)

14. B. Tchórzewska-Cieślak, K. Boryczko, M. Eid, Adv. in Saf., Reliab. and Risk Manag. (Taylor \& Francis Group, 2492-2499, London, 2012)

15. B. Tchorzewska-Cieslak, J. Rak, Environ. Engin. (Taylor \& Francis Group, 521-526, London, 2010)

16. K. Shahata, T. Zayed, Struct. Infrast. 8 (2012)

17. M. Kwietniewski, Failure of water supply and wastewater infrastructure in Poland based on the field tests (In Proceedings of the XXV Scientific-Technical Conference, Międzyzdroje, Poland, 2011)

18. T. Bergel, G. Kaczor, P. Bugajski, Technical condition of water supply networks in small water supply pipes of the Matopolskie and Podkarpackie voivodeships (Infrastructure and ecology of rural areas, Polish Academy of Sciences, Kraków Branch, 2013)

19. K. Pietrucha-Urbanik, A. Studziński, Env. Prot. 18, (2007)

20. J. Rak, Env. Prot. 29, (2016)

21. J. Rak, B. Tchórzewska Cieślak Failure frequency of waters supply networks in the main cities of the San Valley ( $3^{\text {rd }}$ "Blue San" Scientific and Technical Conference, Dubiecko, 2006)

22. D. Szpak, B. Tchórzewska, Chemik 68, 10 (2014)

23. B. Tchórzewska-Cieślak, K. Boryczko, Analysis of the exploitation of the water supply system of the city of Mielec (Polish environmental engineering five years after accession to the European Union, PAN, 58, 1, 2009)

24. K. Świętochowski, Water San. Techn. 5 (2018) 
25. I. Vloerbergh, M. Blokker, Water Asset Manag. Intern. 6 (2010)

26. https://www.stat.gov.pl

27. M. Kwietniewski, J. Rak, Reliability of water supply and wastewater infrastructure in Poland (Institute of Fundamental Techno-logical Research, Warsaw, 2010) 